\title{
Hubungan agama dengan Pancasila dalam perspektif konstitusi
}

\author{
Yusuf Eko Nahuddin ${ }^{1}$, Angga Prastyo ${ }^{2}$
}

${ }^{1}$ Yusuf Eko Nahuddin; Fakultas Hukum Universitas Merdeka Malang; Jl. Terusan Raya Dieng Nomor 62-64; Malang; 65146; JawaTimur; Indonesia.

${ }^{2}$ Angga Prastyo; Fakultas Hukum Universitas Merdeka Malang; Jl. Terusan Raya Dieng Nomor 62-64; Malang; 65146; JawaTimur; Indonesia.

\section{ARTICLEINFO}

Article history:

Received 2020-08-06

Received in revised form

2020-11-01

Accepted 2020-12-01

Kata kunci:

Agama; Pancasila; Undang-Undang

Dasar 1945.

Keywords:

Religion; Pancasila; 1945

Constitution.

DOI: https://doi.org/10.26905/

idjch. v11i3. 4070.

How to cite item:

Nahuddin, Y., \& Prastyo, A.

(2020). Hubungan agama

dengan Pancasila dalam

perspektif konstitusi. Jurnal

Cakrawala Hukum, 11(3). 282-290. doi:10.26905/idjch.v11i3.4070.

Corresponding Author:

* Yusuf Eko Nahuddin.

E-mail address:Yusuf eko@unmer.ac.id

\section{Abstrak}

Penelilian ini merupakan penelitian hukum normatif, menggunakan pendekatan Undang-Undang (statute approach) dan menerapkan metode analisis deskriptif yang dilakukan untuk menganalisis hubungan antara Agama dengan Pancasila dalam perspektif Undang-Undang Dasar 1945, yang meliputi korelasi antara prinsip Agama dengan rumusan nilai-nilai dalam Pancasila, dan kedudukan keduanya dalam Undang-Undang Dasar 1945. Agama menjadi objek kajian yang begitu kompleks dalam kaitannya dengan kehidupan bernegara. Terakhir kali tampak pada pernyataan Yudian Wahyudi (Ketua BPIP) tentang agama sebagai musuh Pancasila. Undang-Undang Dasar 1945 yang diposisikan tertinggi dalam hierarki Peraturan Perundang-undangan merupakan indikator yang tepat dalam mengkaji hubungan antara Agama dengan Pancasila, khususnya dalam kerangka paradigma hukum normatif di Indonesia. Pada pokok analisis hasildan pembahasan, disimpulkanbahwa yaitu Agama merupakan pendukung eksistensi Pancasila, dan Agama tidak dapat dipertentangkan atau dibandingkan dengan Pancasila pada konteks kedudukan dan posisinya dalam kehidupan bernegara dan dalam penyelenggaraan pemerintahan. Hasil tersebut begitu penting bagi upaya perwujudan tujuan negara, guna melandasi penyelenggaraan pemerintahan dalam bernegara yang efektif dan efisien, tanpa mengungkit kembali permasalahan dan perdebatan yang sejatinya telah terselesaikan.

\begin{abstract}
This study is a normative legal research and uses a statute approach and applies a descriptive analysis method which is conducted to analyze the relationship between Religion and Pancasila in the perspective of the 1945 Constitution., and their position in the 1945 Constitution. Religion becomes an object of study that is so complex in its relation to the state. The last time it was seen as the statement of Yudian
\end{abstract}




\title{
Hubungan agama dengan Pancasila dalam perspektif konstitusi \\ Yusuf Eko Nahuddin, Angga Prastyo
}

\begin{abstract}
Wahyudi (Chairperson of BPIP) about religion as an enemy of Pancasila. The 1945 Constitution which is positioned highest in the hierarchy of statutory regulations is an appropriate indicator in examining the relationship between religion and Pancasila, especially in the framework of a normative legal paradigm in Indonesia. In the main analysis of the results and discussion of this study, it was concluded that Religion is a supporter of the existence of Pancasila, and Religion cannot be contested or compared with Pancasila in the context of its position and position in the state and the administration of government. These results are so important for efforts to realize the objectives of the state, in order to underpin the administration of state in an effective and efficient state, without revisiting the problems and debates that have actually been resolved.
\end{abstract}

\section{Pendahuluan}

Yudian Wahyudi sebagai Kepala BPIP (Badan Pembinaan Ideologi Pancasila) dalam sebuah video(Gunawan, 2020)dengan muatan diskusi yang bertajuk "Jihad Pertahankan NKRI" yang diinisiasi oleh detik.com pada 12 Februari 2020, tepatnya pada menit 21:50-21:56 (dalam video dimaksud), menyatakan bahwa musuh terbesar Pancasila adalah Agama dengan menyampaikan "Kalau kita jujur, musuh terbesar Pancasila itu ya Agama." Seketika setelah berita dengan muatan video yang berisi penyataan Ketua BPIP tersebut tersebar, timbul kegaduhan di tengah masyarakat. Pada dasarnya memang sebagian masyarakat pro, tetapi sebagian masyarakat yang lain juga kontra dengan pernyataan kontroversial tersebut.

Tanpa menelusuri mengenai maksud yang sebenarnya atas pernyataan tersebut, dapat dipahami dengan penalaran yang wajar bahwa pernyataan yang dimaksud paling tidak memuat 2 (dua) entitas tanwujud, dimana entitas yang kedua dinyatakan sebagai musuh bagi entitas yang pertama. Pernyataan yang dimaksud juga bersifat analogis dengan digunakannya kata "musuh" dalam mempertentangkan kedua entitas dimaksud. Untuk itu, pernyataan yang demikian dapat dikaji dari berbagai macam perspektif, dan dalam penelitian ini pernyataan tersebut dikaji dalam persektif Hukum dan Peraturan Perundang-undangan, khususnya Undang-Undang Dasar Negara Republik Indonesia Tahun 1945 (Undang-Undang Dasar 1945) sebagai indikator pokok dalam menganalisis.

Entitas yang pertama direpresentasikan dengan kata"Pancasila" yang selama ini diakui dan diterapkan sebagai sumber dari segala sumber hukum dalam ranah ketatanegaraan Indonesia. Keutamaan Pancasila memberikan kesadaran bagi Bangsa Indonesia untuk menjadikannya sebagai rujukan mutlak bagi tatanan kehidupan baik dalam bersosial masyarakat, berpolitik, beragama, maupun berhukum (Bo'a, 2018). Takrif yang menjadi pokok dari dijadikannya Pancasila sebagai rujukan bagi tatanan kehidupan adalah sikap-sikap yang dibutuhkan dalam konteks bernegara. Dalam konteks tersebutlah (yaitu bernegara),Pancasila yang secara umum disepakati oleh masyarakat, dijadikan sebagai rujukan berinteraksi demi kepentingan bersama.

Pada tatanan hukum atau dalam berhukum, kedudukan Pancasila dipertegas sebagai sumber tertib hukum atau yang dikenal dengan sebutan sumber (dari) segala sumber hukum (Bo'a, 2018). Istilah tersebut dikenal dari Ketetapan MPRS Nomor XX/MPRS/1966. Sedangkan Agama sendiri merupakan entitas tanwujudyang secara umum diakui keberadaannya, tetapi belum didefinisikan secara konkrit sebagai sebuah konsep dalam suatu Peraturan Perundang-undangan. 
Pasal 7 ayat (1) Undang-Undang Nomor 12 Tahun 2011 tentang Pembentukan Peraturan Perundang-undangan sebagaimana telah diubah dengan Undang-Undang Nomor 15 Tahun 2019 menjadi rujukan konkrit untuk mengkaji pernyataan yang disampaikan oleh Ketua BPIP sebagaimana yang dimaksud di awal, dimana Undang-Undang Dasar 1945 ditentukan sebagai jenis Peraturan Perundang-undangan yang ditempatkan pada posisi paling tinggi dalam hierarki. Posisi tertinggi Undang-Undang Dasar 1945 dalam penjenjangan Peraturan Perundang-undangan yang didasarkan atas asas bahwa setiapPeraturan Perundang-undangan tidak boleh bertentangan dengan Peraturan Perundang-undangan yang lebih tinggi, mengartikan bahwa setiap Peraturan Perundang-undangan di bawah Undang-Undang Dasar 1945 tidak boleh bertentangan dengan Undang-Undang Dasar 1945. Asas tersebut merupakan representasi dan konkritisasi maxim/ adagium lex superior derogat legi inferioriyang dapat diartikan sebagai peraturan yang lebih tinggi mengenyampingkan peraturan yang lebih rendah, atau dengan pengertian lainPeraturan Perundangundangan yang lebih tinggi akan melumpuhkan peraturan perundang-undangan yang lebih rendah (Suriyani, 2016).

Negara Hukum Indonesia pastinya mengedapankan hukum atau lebih khusus Peraturan Perundang-undangan dalam penyelenggaraan pemerintahannya. Dengan demikian, tepat kiranya mengkaji hubungan antara Agama dengan Pancasila berdasar padaindikator kajian berupa Peraturan Perundang-undangan yang berada pada Posisi tertinggi dalam hierarkinya, yaituUndangUndang Dasar 1945.

\section{Metode}

Penelilian ini merupakan penelitian hukum normatif yang dilakukan untuk menganalisis hubungan antara Agama dengan Pancasila dalam perspektif Undang-Undang Dasar 1945, yang meli- puti korelasi antara prinsip Agama dengan rumusan nilai-nilai dalam Pancasila, serta kedudukan keduanya dalam Undang-Undang Dasar 1945. Penelitian ini menggunakan pendekatan Undang-Undang (statute approach), yaitu dalam konteks penelitian ini analisis yang dilakukan berlandaskan pada prinsip dan ketentuan konstitusi. Adapun analisis deskriptif digunakan sebagai metode analisis yang dilakukan dalam Pembahasan untuk menguraikan hubungan antara Agama dengan Pancasila berdasarkan Undang-Undang Dasar 1945.

\section{Pembahasan}

\subsection{Agama sebagai Pendukung Eksistensi Pancasila}

Kamus Besar Bahasa Indonesia (KBBI) memuat artikata Agama, dandiartikan sebagai ajaran atau sistem yang mengatur tata keimanan (kepercayaan) dan peribadatan kepada Tuhan Yang Maha Kuasa serta tata kaidah yang berhubungan dengan pergaulan manusia dengan manusia, dan manusia dengan lingkungannya. Agama sebagai sebuah sistem aturan bagi seseorang yang menganut ajaranya secara umum disebut sebagai norma Agama yang memiliki sifat universal, berbeda dengan norma hukum yang bersifat mengikat dan memaksa.

Adapun menurut Indrati, yang dimaksud dengan norma adalah suatu ukuran yang harus dipatuhi oleh seseorang dalam hubungannya dengan sesamanya ataupun dengan lingkungannya (Supriyanto, 2016). Secara umum norma agama diyakini sebagai peraturan hidup yang diterima sebagai perintah-perintah, larangan-larangan dan anjuran-anjuran yang berasal dari Tuhan. Norma agama bukan termasuk peraturan yang berasal dari kebudayaan masyarakat, bukan termasuk peraturan yang dibentuk atas dasar kesepakatan, melainkan peraturan yang bersumber dari Tuhan, dan pada umumnya dibawa dan disampaikan oleh 


\section{Hubungan agama dengan Pancasila dalam perspektif konstitusi}

Yusuf Eko Nahuddin, Angga Prastyo

seseorang yang mengaku dan/atau dianggap sebagai utusan Tuhan.

"Agama begitu penting dalam kehidupan manusia, mengandung aspirasi-aspirasi manusia yang paling dalam (sublime), sumber dari semua budaya tinggi, bahkan candu bagi manusia" (Marzali, 2016) kata Karl Marx sebagaimana dikutip oleh O'Dea dalam bukunya The Sociology of Religion.Agama mempengaruhi kebudayaan, kelompok masyarakat, dan suku bangsa (Bauto, 2014).Pernyataan tersebut bukan tanpa alasan, karena pada dasarnya "Perkembangan kepribadian seseorang tidak lepas dari pengaruh lingkungan sosial budaya (termasuk ajaran agama yang menjadi budaya) tempat tumbuh dan berkembangnya seseorang (cultural backround of personality)."(Sutarni. 2018).Kedudukan Agama yang fundamental khususnya sebagai prinsip yang mampumempengaruhi pola kehidupan masyarakat tersebut, membuat agama dengan segala peraturannya menjadi sumber pergerakan dan pembangunan optimisme yang tepat dalam mewujudkan suatu gagasan atau ideologi masyarakat yang sejalan dengan ajaran agama. Gagasan dan ideologi dalam konteks ini adalah Pancasila yang sekaligus berkedudukan sebagai Dasar Negara dan sumber dari segala sumber hukum di Indonesia. Nilai-nilai luhur yangterkandung di dalamnya merupakan nilai-nilailuhur yang digali dari budaya bangsa dan memiliki nilai dasar yang diakui secara universal dan tidak akan berubah olehperjalanan waktu (Octavian, 2018).

Nuansa religius termuat dalam Pembukaan Undang-Undang Dasar 1945 sebagai staats fundamental norm, yaitu norma hukum tertinggi yang bersifat pre-supposed dan merupakan landasan filosofis yang mengandung kaidah-kaidah dasar bagi pengaturan negara itu lebih lanjut (Fauzan, 2016),yang diambil dari Naskah Piagam Jakarta pada Tahun 1945. Dimampukannya rakyat Indonesia dengan diwakili oleh Soekarno dan Mohammad Hatta melalui Proklamasi untuk menyatakan kemerdekaan Indonesia berdasarkan alenia ke-3 Pembukaan Undang-Undang Dasar 1945, diakui sebagai berkat rahmat Allah Yang Maha Kuasa. Besarnya pengaruh dari ajaran agama, dibuktikan dengan dijadikannya agama sebagai dorongan untuk menyatakan kemerdekaan Indonesia, dan ajaran agama dijadikan sebagai landasan dalam bergerak untuk menyatakan kemerdekaan.

Ajaran Agama yang dijadikan sebagai landasan bergerak untuk menyatakan kemerdekaan tersebut, membuatnya menjadi dasar dan landasan untuk menentukan Dasar Negara, Pancasila. Tanpa diterapkannya ajaran agama, dalam konteks Pembukaan Undang-Undang Dasar 1945, maka Dasar Negara juga tidak dapat ditetapkan, karena ajaran Agama merupakan salah satu alasan dari dinyatakannya kemerdekaan Indonesia, selain alasan filosofis dengan dorongan keinginan luhur dan keinginan mewujudkan kehidupan kebangsaan yang bebas. Sebelum ditetapkannya Dasar Negara dalam Pembukaan Undang-Undang Dasar 1945, maka ajaran Agama yang diterapkan, memiliki peran yang fundamental untuk dijadikan sebagai landasan ditetapkannya Dasar Negara. Dasar Negara ditetapkan karena kemerdekaan dinyatakan, dan kemerdekaan dinyatakan atas dasar Rahmat Allah Yang Maha Kuasa, yang notabene merupakan salah satu bagian dari ajaran Agama.

Pancasila lahir dalam suasana kebatinan untuk melawan kolonialisme dan imperialisme, sehingga diperlukan persatuan dan persaudaraan di antara komponen bangsa (Shaleh, 2019). Persatuan dan persaudaraan antar komponen bangsa menjadi sangat penting khususnya untuk menjadikan setiap visi yang diperjuangkan sebelum dan setelah masa kemerdekaan Indonesia dalam lingkup internal tidak terdapat hambatan. Kesepakatan dan kesepahaman dalam setiap sisi pandangan bernegara menjadi perihal yang lebih diutamakan. Sila Pertama dalam Pancasila "Ketuhanan Yang Maha Esa" menjadi 


\section{Jurnal Cakrawala Hukum, Volume 11 No. 3 Desember 2020}

ISSN PRINT 2356-4962 ISSN ONLINE 2598-6538

faktor penting untuk mempererat persatuan dan persaudaraan, karena sejarah bangsa Indonesia penuh dengan penghormatan terhadap nilai-nilai "Ketuhanan Yang Maha Esa." (Shaleh, 2019). Latar belakang tersebut secara otomatis menjadi pertimbangan yang pertama guna mewujudkan persatuan dan persaudaraan untuk membangun kekuatan baik secara kualitas emosional maupun kuantitasnya.

Eksistensi Agama merupakan landasan yang kuat untuk mewujudkan tujuan negara yang didasari oleh Pancasila. Pancasila yang dijadikan filosofi penyelenggaraan kegiatan pemerintahan, kehidupan bermasyarakat dan sebagai Dasar Negara yang sekaligus sebagai paradigma bernegara pada pokoknya memuat lima prinsip bernegara, yaitu ketuhanan (theisme), kemanusiaan (humanisme), kebangsaan (nasionalisme), kerakyatan (demokrasi), dan keadilan sosial, yaitu sosialisme (Jurdi, 2016).Nilai yang pertama secara langsung merepresentasikan Agama sebagai Dasar Negara yang utama untuk dipertimbangkan dalam setiap tindakan bernegara, dan landasan utama dalam penyelenggaraan pemerintahan. Pengakuan terhadap eksistensi Agama dalam konteks ini, menunjukkan bahwa Agama menjadi sumber pokok nilai-nilai kehidupan bangsa Indonesia (Syafi' AS. 2016). Mempertimbangkan kesesuaian antara setiap tindakan dalam bernegara atau dalam penyelenggaraan pemerintahan dengan ajaran Agama merupakan tahapan utama yang harus divalidasi atau diverifikasi terlebih dahulu.

Berdasarkan konteks ajaran Agama sebagai landasan dalam bergerak untuk menyatakan kemerdekaan, ajaran Agama sebagai salah satu landasan ditetapkannya Dasar Negara sekaligus paradigma bernegara, serta Agama sebagai indikator yang pertama dalam menentukan tindakan dalam rangka mewujudkan tujuan negara dan penyelenggaraan pemerintahan, maka dalam konteks tersebut ajaran Agama yang diterapkan berkedudukan sebagai pendukung eksistensi Pan- casila sebagai Dasar Negara sekaligus sumber dari segala sumber hukum di Indonesia.

\subsection{Agama dengan Pancasila Tidak Dapat Dipertentangkan}

Falsafah negara merupakan dasar filosofis bernegara, yang mencerminkan keinginan, watak, kepribadian, karakter, ciri khas, dan keistimewaan suatu negara yang dirumuskansesuai dengan karakter bangsa yang mendirikannya. Karena falsafah itu merupakan perwujudan dari watak dan keinginan dari suatu bangsa, segala aspek kehidupan bangsa tersebut harus sesuai dengan falsafahnya (Huda, 2016). Bangsa Indonesia sendiri memilih Pancasila sebagai falsafah negara, sehingga dalam bernegara, baik Pemerintah beserta seluruh komponen masyarakatnya dalam bertindak demi kepentingan pencapaian tujuan negara, harus sesuai dengan prinsip-prinsip yang dimuat dalam Pancasila yang diwarnai oleh aspirasi-aspirasi keindonesiaan (Fadjar, 2016). Selain sebagai falsafah negara, Pancasila sebagaimana pembahasan yang sebelumnya juga berkedudukan sebagai Dasar Negara. Dasar Negara itu sendiri merupakan prinsip yang digunakan sebagai landasan didirikannya suatu negara, landasan yang menjadi sumber dan prinsip hukum nasional, dan dasar kegiatan penyelenggaraan negara.

Pancasila sebagai Dasar Negara mempunyai sifat imperatif/memaksa, artinya setiap warga Negara wajib tunduk taat kepadanya (Syafi' AS, 2016).Kata "wajib" dalam penyataan tersebut tidak terkait dengan ketentuan hukum, sehingga tidak berkonseskuensi terhadap diberlakukannya sanksi apabila terbukti tidak ditaati, dan pastinya tidak dapat serta-merta dilakukan (penghukuman) karena memang bukan ketentuan hukum, kecuali memang secara khusus diatur di dalam UndangUndang maupun Peraturan Perundang-undangan lainnya. Pernyataan tersebut ditekankan untuk me- 


\section{Hubungan agama dengan Pancasila dalam perspektif konstitusi}

Yusuf Eko Nahuddin, Angga Prastyo

nunjukkan prinsip yang fundamental dalam rangka menjalankan setiap kegiatan bernegara, dan menunjukkan urgensi penggunaan nilai-nilai yang terkandung didalamnya. Dalam konteks Pancasila sebagai Dasar Negara khususnya pada bidang hukum, maka lebih tepat apabila Pancasila diposisikan sebagai indikator untuk menilai suatu Peraturan Perundang-Undangan.

Diposisikannya ajaran agama dalam Sila Pertama Pancasila, bukanlah tanpa maksud. Telah jelas dalam Pasal 29 ayat (1) Undang-Undang Dasar 1945, ditentukan bahwa Negara (Indonesia) berdasarkan atas Ketuhanan Yang Maha Esa. Ketentuan tersebut merupakan penegasan bahwa kehidupan bernegara dan penyelenggaraan pemerintahan harus berdasarkan atas ajaran Agama. Sila Pertama Pancasila merupakan bagian inti dari pancasila yang merepresentasikan sifat religius multikultiralisme. Tanpa tuntutan kejelasan atas Dasar Negara yang kemudian hari dijadikan sebagai sumber dari segala sumber hukum, Sila Ke-2 sampai dengan Sila Ke-5 sebenarnya telah terakomodir dengan adanya Sila Pertama Pancasila.

Keutamaan dan pengaturan mengenai Agama dalam Undang-Undang Dasar 1945, dapat dipahami melalui ketentuan Pasal 9 ayat (1), Pasal 9 ayat (2), Pasal 28 E ayat (1), Pasal 22D ayat (2), Pasal 22D ayat (3), Pasal 28I ayat (1), Pasal 28J ayat (2), Pasal 29 ayat (1), Pasal 29 ayat (2), Pasal 31 ayat (3),dan Pasal 31 ayat (5), dimana pada pokoknya memuat ketentuan sebagai berikut:

a. Agama sebagai dasar dan prinsip ajaran yang diikuti oleh Presiden dan Wakil Presiden untuk bersumpah atau berjanji sebelum memangku jabatan;

b. Agama sebagai entitas nonfisik yang secara konstitusional dijadikan sebagai objek yang berhak dipeluk oleh setiap orang;

c. Agama sebagai salah satu objek Rancangan Undang-Undang;

d. hak berAgama adalah hak asasi manusia yang tidak dapat dikurangi dalam keadaan apapun;

e. nilai-nilai Agama sebagai salah satu komponen pertimbangan dijalankannya hak dan kebebasan konstitusional;

f. ajaran Agama sebagai dasar Negara;

g. adanya jaminan konstitusional atas kemerdekaan tiap-tiap penduduk untuk memeluk Agamanya;

h. terwujudnya sifat dalam ajaran Agama sebagai salah satu tujuan penyelenggaraan pendidikan nasional; dan

i. nilai-nilai agama dijunjung tinggi dalam memajukan ilmu pengetahuan dan teknologi.

Mempertentangkan Agama dengan Pancasila berdasarkan ketentuan-ketentuan UndangUndang Dasar sebagaimana yang telah disebutkan tersebut, bukanlah langkah yang rasional. Demikian adanya, karena Agama merupakan Dasar Negara yang menjadi sumber dan pertimbangan utama atas tindakan bernegara seluruh komponen masyarakat maupun Pemerintah yang didasari oleh Sila Pertama Pancasila. Dalam kontek hukum nasional, Sila Pertama Pancasila yang merepresentasikan nilai Ketuhanan, mengamanatkan bahwa tidak boleh ada produk hukum nasional yang bertentangan dengan agama atau bersifat menolak atau bermusuhan dengan agama (Mochtar Kusumaatmadja dan Arief Sidharta, 2000). Dengan pengertian tersebut, agama merupakan indikator mutlak untuk menilai sebuah produk hukum nasional sesuai dengan Pancasila sebagai Dasar Negara atau tidak.

Agama dalam konteks sebagai ajaran-ajaran peribadatan, baik dalam hubungan manusia dengan Tuhan maupun manusia dengan manusia lain serta lingkungannya, tidak setara kedudukannya dengan Pancasila sebagai Dasar negara, untuk itu keduanya tidak dapat dipertentangkan maupun diperbandingkan. Agama dalam konteks sebagai ajaran (yang dapat diikuti dan diterapkan) tersebut, menjadi salah satu sumber dari prinsip-prinsip bernegara. Sedangkan Pancasila merupakan hasil dari seleksi kontemplatif konseptor negara 


\section{Jurnal Cakrawala Hukum, Volume 11 No. 3 Desember 2020}

ISSN PRINT 2356-4962 ISSN ONLINE 2598-6538

atas prinsip universal yang merepresentasikan (dinilai sebagai) kepribadian bangsa atau ciri khas masyarakat Indonesia, yang dijadikan sebagai Dasar Negara dan sumber dari segala sumber hukum di Indonesia.

Agama dan Pancasila saling memperkuat satu sama lain dalam konteks sebagai prinsip yang berperan untuk melandasi upaya mewujudkan tujuan negara pada posisinya masing-masing. Agama berperan sebagai prinsip yang digunakan untuk membentuk kepribadian masyarakat secara subjektif dan kultural sedangkan Pancasila yang ditetapkan sebagai Dasar Negara berkonsekuensi bahwa dalam hukum, baik penerapan dan pelaksanaannya tidak dapat dilepaskan dari nilai-nilai Pancasila (Sutrisno, 2016). Dengan demikian, dalam konteks tersebut Pancasila digunakan sebagai prinsip untuk membentuk secara tidak langsung kepribadian setiap komponen masyarakat yang direpresentasikan dengan hukum dan tata penyelenggaraan pemerintahan, dimana pada umumnya hasil dari representasi atau konkretisasi Pancasila ke dalam Peraturan Perundang-undangan sebagai hukum, bersifat mengikat dan memaksa.

Mengutip pernyataan dari Muhyar Fanani, Kamaruddin menyebutkan bahwa:

"Relasi agama dan negara di Indonesia yang berasaskan Pancasila amat sinergis dan tidak pada posisi dikotomi yang memisahkan antara keduanya, karenanya, Indonesia sering juga disebut religious nation state atau negara kebangsaan yang dijiwai oleh agama." (Kamaruddin, 2013)

EksistensiAgama dan Pancasila dalam peranannya masing-masing tidak dapat serta-merta dipertentangkan maupun dibandingkan. Pancasila sebagai hasil negosiasi dan kompromi antar pendiri konseptor negara dan pemersatu bangsa mempunyai kekuatan yang mutlak sebagai Philosofische Grondslag/Dasar Negara berdasarkan
Undang-Undang Dasar 1945. Pancasila dalam posisi tersebut pada hakikatnya tidak dapat diubah, karena"... posisi dan kedudukan hukum Pancasila adalah sebagai norma dasar (grundnorm) yang sifatnya meta legal dan berada di atas UUD" (Basarah, 2016). Berdasarkan teori hukum murni Hans Kelsesn, norma dasar (grundnorm) merupakan sesuatu yang dikehendaki yang bersumber dari keinginan rakyat melalui para pendiri bangsa. Oleh karena merupakan kehendak bersama, maka grundnorm tidak dapat berubah-ubah dan bersifat mengharuskan (Basarah, 2016). Untuk itu, Pancasila sebagai norma dasar tidak dapat diubah, dan secara otomatis Sila Pertama Pancasila tetap eksis juga sebagai Dasar Negara.

Pancasila sebagai hasil dari negosisasi dan kompromi antara pendiri bangsa yang dijadikan sebagai falsafah kenegaraan atau staatsidee (cita negara) yang berfungsi sebagai filosofische grondslag dan common platforms atau kalimatun sawa dalam konteks kehidupan bernegara (Asshiddiqie, 2015), pastinya memiliki kedudukan yang tidak setara dengan kedudukan Peraturan Perundang-undangan lainnya, karena secara prinsip memang bukan termasuk Peraturan Perundang-undangan, melainkan sumber filosofis dari Peraturan Perundangundangan yang dibentuk. Begitupun Sila Pertama Pancasila yang bersifat Agamis, mempunyai kedudukan yang kuat sebagai dasar negara, baik secara hukum berdasarkan Pasal 29 ayat (1) Undang-Undang Dasar 1945, maupun secara historis proses pembentukannya. Pengaruh Sila Pertama Pancasila, diuraikan oleh Kamaruddin sebagai berikut:

"Sila Pertama Pancasila (sebagai konsensus publik), jelas-jelas menghendaki agar nilai-nilai Ketuhanan mendasari kehidupan publik-politik, pada saat yang sama negara juga diharapkan melindungi dan mendukung pengembangan kehidupan beragama sebagai wahana untuk menyuburkan nilai-nilai etis dalam kehidupan publik." (Kamaruddin, 2013) 


\section{Hubungan agama dengan Pancasila dalam perspektif konstitusi}

Yusuf Eko Nahuddin, Angga Prastyo

Tidak dapat dipertentangkannya Agama dengan Pancasila merupakan konsekuensi langsung dari kesatuan sistematis hasil negosiasi dan komromi pendiri bangsa dalam bentuk Dasar Negara, Pancasila. Dalam konteks ini, dipertentangkannya Agama yang direpresentasikan dengan Sila Pertama dengan Pancasila yang memuat 5 (lima) nilai filosofis dalam bernegara merupakan tindakan yang irasional, karena Agama sendiri telah eksis di dalam Pancasila melalui Sila Pertama Pancasila. kesatuan sistematis dari tiap Sila Pancasila, diuraikan sebagai berikut:

Pengejawantahan nilai-nilai Pancasila di Indonesia dijabarkan dalam tiap sila Pancasila, dimana sila satu dengan sila yang lain merupakan kesatuan yang sistematis. Artinya, tiap sila dalam Pancasila menjiwai sila-sila yang lain. Nilai-nilai tersebut harus dijadikan pedoman dan dihayati dalam setiap penyelenggaraan negara maupun dalam kehidupan sehari-hari serta setiap perbuatan tidak boleh bertentangan dengan Pancasila. ${ }^{1}$

Penegasan atas sila yang satu dengan sila yang lain dalam Pancasila merupakan satu-kesatuan, menunjukkan bahwa antar sila Pancasila tidak dapat saling dikesampingkan. (Muslimin, 2016) Diterapkannya ajaran Agama sebagai landasan dari ditetapkannya sila pertama Pancasila dalam konteks tersebut tidak dapat dipermasalahkan, apalagi dihadap-hadapkan sebagai prinsip tandingan Pancasila. Dalam arti demikian, prinsip yang terdapat diantara keduanya (Agama dengan Pancasila) satu dengan yang lain tidak dapat saling dipertentangkan. Pancasila yang di dalamnya memuat ajaran Agama khususnya dalam sila Pertama, dengan sendirinya tidak dapat dipertentangkan dengan Agama itu sendiri. Agama sebagai salah satu sumber prinsip Pancasila dengan sendirinya menyatu dengan Pancasila itu sendiri, dan berada pada kedudukan yang berbeda, sehingga tidak dapat dihadap-hadapkan dan diperbandingkan.

\section{Simpulan}

Berdasarkan pada Pembahasan sebagaimana yang telah diuraikan, dalam perspektif UndangUndang Dasar 1945, Agama merupakan entitas tanwujud sekaligus menjadi prinsip masyarakat yang diakui keberadaannya di Indonesia, dan berkedudukan sebagai pendukung eksistensi Pancasila sebagai Dasar Negara dan sumber dari segala sumber hukum Indonesia. Selain itu, Agama tidak dapat dipertentangkan dengan Pancasila, karena dalam konteks Undang-Undang Dasar 1945, Agama merupakan bagian utama dari nilai yang terkandung dalam Pancasila, dan Agama tidak setara kedudukannya dengan Pancasila, melainkan menyatu dengan Pancasila, sehingga secara rasional dan penalaran yang wajar keduanya tidak dapat diperbandingkan maupun dipertentangkan. Sebaliknya, keduanya saling memperkuat satu sama lain sebagai prinsip untuk melandasi upaya mewujudkan tujuan negara.

\section{Daftar pustaka}

AS, A. Syafi'. 2016. Pengaruh Nilai-Nilai Pancasila dan Ajaran Islam terhadap Tujuan Pendidikan Nasional.Jurnal Sumbula: Volume I, Nomor I, Januari-Juni.

Asshiddiqie, Jimly. 2015. Konstitusi Bernegara: Praksis Kenegaraan Bermartabat dan Demokratis. Setara Press. Malang.

Bauto, Laode Monto. 2014. Perspektif Agama dan Kebudayaan dalam Kehidupan Masyarakat Indonesia (Suatu Tinjauan Sosiologi Agama).Jurnal Pendidikan Ilmu Sosial (JPIS), Volume 23, No. 2, Desember.

Bo'a, Fais Yonas. 2018. Pancasila Sebagai Sumber Segala Sumber Hukum dalam Sistem Hukum Indonesia.Jurnal Konstitusi, Volume 15, Nomor 1, Maret.

Fadjar, Abdul Mukthie. 2016. Sejarah, Elemen, dan Tipe Negara Hukum. Setara Press. Malang.

Fauzan, Encik Muhammad. 2016. Hukum Tata Negara Indonesia. Setara Press. Malang. 


\section{Jurnal Cakrawala Hukum, Volume 11 No. 3 Desember 2020}

ISSN PRINT 2356-4962 ISSN ONLINE 2598-6538

Gunawan, Deden. 2020. Kepala BPIP Sebut Agama Jadi Musuh Terbesar Pancasila. Detik News (daring), diakses pada 5 Maret 2020. https:// news.detik.com/berita/d-4895595/kepalabpip-sebut-Agama-jadi-musuh-terbesarpancasila

Huda, Ni'matul. 2016. Hukum Tata Negara Indonesia. Edisi Revisi, Cetakan Kesebelas. Rajawali Pers. Jakarta.

Jurdi, Fajlurrahman. 2016. Teori Negara Hukum. Setara Press. Malang.

Kamaruddin. 2013. Dimensi Sila "Ketuhanan Yang Maha Esa" dalam Perspektif HAM Islam.Jurnal Agama dan Hak Azazi Manusia (In Right) Volume 3, Nomor I.

Kusumaatmadja, Mochtar, dan Arief Sidharta. 2000. Pengantar Ilmu Hukum: Suatu Pengenalan Pertama Ruang Lingkup Berlakunya Ilmu Hukum. Alumni. Bandung.

Marzali, Ali. 2016. Agama dan Kebudayaan. Indonesian Journal of Anthropology (UMBARA), Volume I No. 1, Juli.

Muslimin, H., 2016. Tantangan terhadap pancasila sebagai ideologi dan dasar negara pasca reformasi. Jurnal Cakrawala Hukum, 7(1), pp.30-38.
Octavian, Wendy Anugrah. 2018. Urgensi Memahami dan Mengimplementasikan NilaiNilai Pancasila dalam Kehidupan Sehari-Hari sebagai Sebuah Bangsa. Jurnal Bhinneka Tunggal Ika, Volume 5, Nomor 2, Oktober.

Pinilih, Sekar Anggun Gading dan Sumber Nurul Hikmah. 2018. Aktualisasi Nilai-Nilai Pancasila terhadap Hak Kebebasan Beragama dan Beribadah di Indonesia. Jurnal Masalah-Masalah Hukum, Jilid 47 Nomor 1, Januari.

Putra, E. N. (2015). Kejahatan Tanpa Korban Dalam Kejahatan Cyberporn.

Shaleh, Ali Ismail dan Fifiana Wisnaeni. 2019. Hubungan Agama dan Negara Menurut Pancasila dan Undang-Undang Dasar Negara Republik Indonesia Tahun 1945. Jurnal Pembangunan Hukum Indonesia.Volume 1, Nomor 2, Mei.

Suriyani, Meta. 2016. Pertentangan Asas Perundang-undangan dalan Pengaturan Larangan Mobilisasi Anak pada Kampanye Pemilu.Jurnal Konstitusi, Volume 13, Nomor 3, September.

Sutrisno. 2016. Peranan Ideologi Pancasila dalam Perkembangan Konstitusi dan Sistem Hukum Indonesia.Jurnal Pancasila dan Kewarganegaraan (JPK): Volume 1 Nomor 1, Juli. 